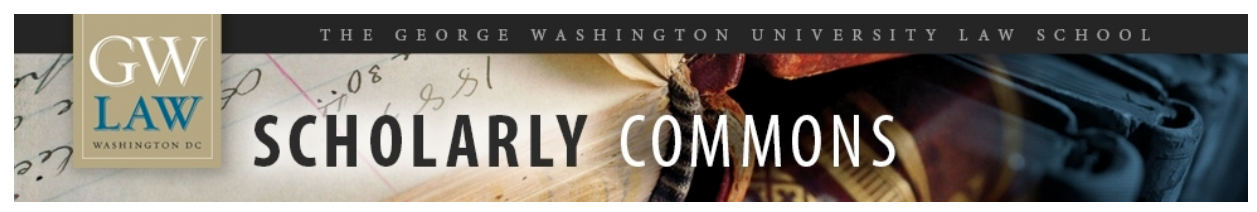

\title{
From Convergence to Comity in Corporate Law: Lessons from the Inauspicious Case of SOX
}

Lawrence A. Cunningham

George Washington University Law School, lacunningham@law.gwu.edu

Follow this and additional works at: https://scholarship.law.gwu.edu/faculty_publications

Part of the Law Commons

\section{Recommended Citation}

Lawrence A. Cunningham, From Convergence to Comity in Corporate Law: Lessons from the Inauspicious Case of SOX in International Journal of Disclosure and Governance (Henry Stewart Publications, 2004)

This Article is brought to you for free and open access by the Faculty Scholarship at Scholarly Commons. It has been accepted for inclusion in GW Law Faculty Publications \& Other Works by an authorized administrator of Scholarly Commons. For more information, please contact spagel@law.gwu.edu. 


\title{
From Convergence to Comity in CORPORATE LAW:
}

\author{
LESSONS FROM THE INAUSPICIOUS CASE OF SOX
}

\author{
Lawrence A. Cunningham
}

\begin{abstract}
International Journal of Disclosure and Governance, vol. 1 no. 2 (forthcoming 2004).
Edited by John Friedland and Cass Business School, London.

Published by Henry Stewart Publications, ISSN 1741-3591, London.
\end{abstract}

\begin{abstract}
The Sarbanes-Oxley Act shook the corporate world beyond US borders more than Enron shook the corporate world within them. This Article goes beyond the prodigious commentary on the Act itself to understand the nature of its reception outside the US.

It first develops a hubs-and-spokes account of global corporate life in which corporate purpose, which varies around the world, forms the hub and radiates spokes constituting governance, finance, accounting, and auditing-all of which also differ around the world. Using this model, the Article suggests that non-US receptions to the Act exhibited unfounded fear that the exportation of US norms concerning the spokes of corporate life could redefine corporate conceptions of the hub, corporate purpose. It also shows the fallacy in the noscandal-here argument emanating from countries around the world.

Although global reactions to the Act may therefore have been somewhat overstated, the Act certainly carried a whiff of exporting US corporate norms around the world by fiat. A key lesson for the US is the next time US corporate scandals erupt and Congress adopts a legislative response, it should automatically exempt non-US issuers pending SEC determinations of the necessity of applying the reforms to them.

A related implication of this model and interpretation concerns debate over whether corporate life around the world is converging to a single model or remaining path dependent and varied. Moves like SOX seem to change the character of both the debate and the direction of evolving corporate life. The normative payoff contends that the superior road to harmonious corporate life is in developing comity rather than hoping for convergence.
\end{abstract}




\title{
From CONVERGENCE TO COMITY IN CORPORATE LAW: \\ LESSONS FROM THE INAUSPICIOUS CASE OF SOX
}

\author{
Lawrence A. Cunningham*
}

\section{$\underline{\text { Table of Contents }}$}

Introduction

I. SOX’s Clumsy Global Reach

II. The Hubs and Spokes of Global Corporate Life
A. The Landscape
B. Enter SOX

III. SOX's Global Reception

A. Public Reactions

B. Reinterpreting the Public Reactions

IV. Imprecision in the No-Scandal-Here Criticism

V. From Convergence to Comity

A. The State of Convergence as a State of Mind

Conclusion: The Road to Comity

End Notes

* Professor of Law and Business, Boston College; Visiting Professor of Law, Vanderbilt University Law School. (C) Lawrence A. Cunningham, 2003. All rights reserved. E-mail: Lawrence.Cunningham@BC.edu. 


\section{Introduction}

United States capital market regulation amid globalization addresses the world. Ten percent of SEC registrants are non-US issuers, commanding market capitalizations constituting nearly $20 \%$ of the US total. Sixty countries are represented directly, home to 1400 non-US companies operating in every nook of the globe, triple the number of a decade ago. ${ }^{1}$ When US regulation enters the internal governance of SEC registrants, as the US Sarbanes-Oxley Act of 2002 does (non-affectionately known abroad as SOX), ${ }^{2}$ US capital market regulation is no longer purely domestic policy but assumes an international relations dimension.

This subtly profound point was missed by US lawmakers who rushed SOX into the global business landscape in July 2002 as a response to a series of US corporate debacles. ${ }^{3}$ Political blindness to the international relations viewpoint was evident from the US failure to consult regulatory counterparts abroad and from the heated political rhetoric accompanying SOX, which trumpeted the legislation as the most sweeping reform of American business practices since the 1930s. ${ }^{4}$ When adopted, SOX made no distinction between US issuers and non-US issuers, though in the year following enactment the SEC adopted numerous exemptions for the latter.

By US standards, SOX is essentially a codification of existing rules and practices, fitting easily if awkwardly into the US corporate template. ${ }^{5}$ For many non-US issuers, the fit is alien, superfluous or conflicting. Though many SOX provisions could be adapted to fit non-US issuers, the entire character of SOX is American. It is legislation appearing to export US corporate norms by fiat. If it worked, this would alter the shape of corporate life in other countries. This may or may not be desirable from the viewpoint of any given country or the world at large, but attempting the export without the courtesy of consultation exhibits an unbecoming arrogance that caused substantial ruckus in the global corporate community.

SOX marks the first US Congressional foray into corporate regulation since globalization transformed the world during the 1990s. It also marks the first time that regulation has reached inside the internal affairs of SEC registrants. These unprecedented moves occur at a time when enormous pressures have led towards significant harmonization of global corporate life, but where substantial resistance to change endures. SOX's adoption without foreign consultation threatened to upset the somewhat delicate balance of the process towards harmonization.

The potential disruption arises without regard to which of two rival schools of thought on comparative corporate philosophy one holds. One school announces the inevitability of marketoriented structures based on the US model. All other models are converging toward this ideal, according to this stance. The competing view sees greater path dependence in the way of this evolution, with the consequences of historical choices derailing such convergence.

Both theories explain important aspects of the contemporary global corporate condition. Chosen paths throw obstacles on the track towards free market liberalism while that model remains the only one with both proven success and promise. But viewing SOX as an exercise of formal exportation of US corporate norms, on a take-it-or-leave-it basis, alters this debate's character. It matters less whether models left to their own operation would move in this 
direction or resist it; SOX injects an exogenous factor into the process, whatever course it would follow without it. In fact, the international ruckus arising from SOX is noisier than its substance warrants, suggesting US corporate regulation of non-US issuers risks altering the course of convergence by provoking backlash.

With SOX as its first legislative venture into corporate regulation in the globalized world, the US Congress and President failed to appreciate the new international relations dimension of US corporate regulation amid globalization. But SOX's relative modesty furnishes a relatively cheap lesson for the future, a lesson the SEC was taught in the year following SOX as it provided exemptions in response to vociferous lobbying objections of countries and companies around the world. $^{6}$ In the future when Congress regulates US capital markets and SEC registrants, it should not punt to the SEC to hedge the resulting international relations fall-out but address that thicket up-front.

This Article has five Parts. Part I reviews the global reach of US securities regulation. Part II canvases comparative corporate life, showing varying conceptions of corporate purpose in the world's major economies and how these radiate different tools of finance, governance, accounting, and auditing. Part III considers the static accompanying global reception of SOX. Its point is that global complaints against SOX have less to do with formal conflict and are more concerned with the deeper level of threats it carried to redefine basic conceptions of corporate purpose around the world. Part IV reinforces this understanding by showing as imprecise the common criticism that while SOX was necessary to fix American problems, other countries did not share the problems or need the fix. Other countries have problems of corporate malfeasance too, though they constitute deviations from different norms, suggesting that SOX-type provisions are not unnecessary elsewhere, though different versions of them may be better suited to addressing subtly different sorts of deviations.

The final Part draws a further normative point, that whatever direction global corporate life is taking-convergence or sustained divergence-measures such as SOX when adopted without consultation can disrupt the process of harmonization. A prescriptive point follows: the next time the US Congress adopts corporate regulations addressed to domestic corporate power abuse, it should automatically stay application of the law as to non-US issuers until and unless the SEC determines that such application is necessary and appropriate for the protection of US investors and US markets. If this were done with SOX, the world would have arrived at the same place, without undesirable political agitation, anxiety, and backlash risks. This underscores the international relations aspect of US corporate regulation amid globalization.

\section{SOX's Clumsy Global Reach}

SOX is global. It applies to any issuer of securities registered with the SEC, as well as any auditor wherever located attesting to the financial statements of such issuers. The heavy rhetoric accompanying SOX echoed world wide, recognized as bearing substantial significance. The global sobriquet "SOX" suggests a perceived whiff of noxiousness abroad.

Of the some 14,000 SEC registrants, approximately 1,400 are non-US entities, representing some 60 countries. About 240 registrants come from the "vital" global economies 
of the UK, Japan, France and Germany. ${ }^{8}$ These aggregate US\$2.4 trillion in market capitalization. Another 160 represent other European countries, including a handful from Eastern Europe. ${ }^{9}$ About 60 non-Japanese Asian companies are SEC registrants, including companies from China, India and Russia. ${ }^{10}$ Nearly 200 SEC registrants hale from Canada, another 200 from Latin America, ${ }^{11} 90$ others from Israel, and a dozen more from elsewhere in the Middle East and Africa. ${ }^{12}$

These figures all represent historic peaks and enormous feats. The vast majority of SEC non-US issuers arose during the 1990s, including all those from South America and nonJapanese Asia. In 1991, no registrants haled from any Eastern European countries, China or Russia; nor were Germany, France or Switzerland represented. Also in 1991, there were only 19 UK companies, 8 Japanese companies and 5 Dutch companies listed on US exchanges. ${ }^{13}$

The substantial international scope of US capital markets epitomizes globalization. ${ }^{14}$ The reach of US capital market regulation requires attention to its global effects. Pre-SOX practice gave pre-enactment exemption to non-US issuers and their auditors from rules relating to corporate governance. SOX makes no such provisions and the SEC work toward doing so followed several quarters after enactment as a response to intense foreign lobbying. ${ }^{15}$

US corporate regulation may be aimed predominately at US capital markets and to that extent constitutes domestic policy. But since a large and growing segment of those addressed are non-US entities and their internal regulatory apparatuses, it trips into international relations. SOX stamps US norms on non-US entities. The stamp produces significant international reactions, implicating matters of international relations.

Apart from the UK, European nations cast a more collectivist orientation than the individualist attitude prevalent in the US. Their embrace of markets, while significant, is more modest than that of the US or the UK. High levels of taxation and a more substantial commitment to state-supplied social safety-nets distinguish European custom from AngloAmerican practice. The character of the competition between Europe and the US, with the UK continuing its dualist role, is influenced by these varying philosophical commitments to collectivist versus individualist solutions to economic and social challenges. European inclination towards the purer-market US corporate model hinges on the smoothness of the process of moving from collectivist to individualist orientations.

Unresolved historical tensions between Asian nations, geographical expansiveness and political flux combine to render elusive contemporary analysis of comparative corporate governance and financial reporting encompassing Asia (other than of the vital and ascendant components such as Japan and Korea). ${ }^{16}$ The sheer diversity of these countries, the substantial multi-ethnicity of many (especially China, India, Indonesia and Russia), and the complexities of corporate character make Asian relations with the US and absorption of US models far more complicated than in Europe. Even greater sensitivity is required to address local concerns, and the stakes of failure higher given regional volatilities.

Globalization, trade, and corporatism have benefited Latin America, spawning a political and economic vitalization on par with the concurrent transformation of Eastern Europe and the 
erstwhile Soviet Union. ${ }^{17}$ Inflation is controlled, democratic institutions are strengthening, and no military build-ups are in progress. Improvements remain necessary in critical areas such as education, property rights, and non-bribable judges.

The downside is also acute: the gap between rich and poor is so wide that Latin America consists of two-tiered societies in which the elite minority is integrated internationally and the vast populace is insulated. ${ }^{18}$ Asset ownership is moving toward multinational corporations, threatening to create public perception of eroding national sovereignty that could provoke backlashes against globalization and the US. ${ }^{19}$ Nurturing corporate life while spreading its bounties are both critical to avoiding such a result. The right corporate norms for contemporary Latin America as it struggles with these challenges may not be the same as those prevalent in the US and embodied in SOX.

Almost every corner of the world, even the most unlikely, participates in globalization. But the US is both the driving force and the prime beneficiary. Global economic growth in the 1990s was propelled by economic interdependence through global capital markets. One effect of global market rule is to curtail the nation-state's power to control local economic destiny. ${ }^{20}$ One risk of that is an internal vacuum that places greater strain on the state's exercise of political power amid economic paralysis.

For Europe this risks over-reliance on collectivist solutions; for Latin America it risks revolts of those left out of globalization's bounties and authoritarian political temptations for their leaders; for Asia, it risks both of these coupled with the threat of fundamentalist uprisings and nuclear militancy; for Africa, it risks criminal and terrorist exploitation of that continent's vulnerabilities as a money- laundering and terrorist training safe haven.

Free market globalization remains the most promising and only proven route to economic prosperity and human freedom. As the lone beacon, this reinforces the power and allure of the market model, particularly of the US variety. Countries and companies seeking capital must prepare to participate in the markets, meaning globalization. Joining the process puts more wealth in the hands of investors, reinforcing the globalization circle. Reinforcement of the circle too rapidly increases the risks of backlash geometrically with every repetition. ${ }^{21}$

Managing these risks requires cautious exercise of the instruments of globalization. This means acting in ways that sustain the possibility of important measures of local power capable of addressing market failures in democratic and peaceful ways. SOX-like imposition of US norms on local companies threatens that capability for those supervising local markets. Markets work wonders and they also fail. They should be allowed to do both, but societies reaping gains from the wonders - led by the US - should be cautious when reaching into the internal corporate affairs of local companies since that reach hazards unintended consequences.

Globalization can continue to promote and spread prosperity only if its benefits are seen as available to all. A distinctive feature of the US system is precisely that those in the bottom and middle of the economic pecking order overwhelmingly believe that someday they or at least their children may well be in the top. Making such opportunities available elsewhere is not as easy as remaking the world in the US's image, or remaking multinational corporations in the 
image of corporate America. ${ }^{22}$ The US market system and corporate America required decades to mature and remain far from perfect.

Leading copycats are groping towards the model, imperfectly. China is soaring economically but getting nowhere democratically. Russia remains mostly non-market and nondemocratic despite a decade of struggle and billions of aid. In long-nurtured and richlydeveloped Japan a decades-long bout of recession lingers. Even in longstanding liberal, marketoriented democracies across Europe, economic and political challenges endure that sustain collectivist tendencies. In this world, SOX and other impositions of US norms by legislative command are dangerous - even in those countries best able to adapt and comply.

\section{The Hubs and Spokes of Global Corporate Life}

National conceptions of corporate purpose differ around the world. Alternative conceptions of corporate purpose include maximizing profits, promoting business survival, promoting the state, maximizing size and power, or even providing employment. The corporations in vital countries may be seen to pursue a combination of these goals. Varying significantly is the emphasis on one or the other as the guiding mission, the one pursued when trade-offs must be made. ${ }^{23}$

Despite differences in conceptions of corporate purpose, some of the tools employed to measure, monitor, and assess achievement of purpose appear similar across the globe. Others are converging. A nation's conception of corporate purpose influences the choice of tools it uses in corporate governance and how these tools are described. A broad issue of comparative governance is whether changes in the tools of corporate life - such as financing sources - are powerful enough to influence changes in the specification of corporate purpose - such as shareholder wealth maximization or creditor protection.

\section{A. The Landscape}

In the US and UK (as well as in Australia, Canada, and Israel), the guiding corporate goal is to make profits. Pressure to put the interests of other constituencies ahead of shareholders invariably achieves marginal success. The only clear winners have been employees amid hostile takeover efforts, and often incumbent management. Disputation is best conceptualized according to how to split up the pie, not so much to assure its growth, survival, or nationalistic identity. Resulting rules and norms emphasize shareholders as owners and mostly contain provisions designed to promote the corporate mission of enhancing their claims measured by net operating profits. Provisions of SOX are squarely in this conception.

In Germany (and to a lesser but meaningful degree such countries as Austria and Switzerland), survival and business continuity are the key goals. The corporation is seen as a multi-constituted engine absorbing centrifugal resources and spinning off payouts in all directions. That engine must hum, continually. There is a sense of the famously engineering culture in this, of longevity, endurance, performance over the longest possible time horizon. ${ }^{24}$ 
In France corporate goals are more nationalistic. French corporate culture reflects a deeply-forged industrial policy possessing the peculiar characteristics of French capitalism, a socialistically-oriented philosophy. In it the ultimate mission of aggregating resources and distributing goods and services is a consciously organized joint effort of the state and private institutions. $^{25}$ Motifs of the model include a high degree of state equity ownership and control; an elite cadre of technocrats that migrates easily between governmental and industrial service. ${ }^{26}$

The state-industry identity appears as a force in Japan but there is yoked for the distinctly different joint purpose of enlarging corporate power and market share. ${ }^{27}$ A steady flow of managers moves from governmental posts to industry and sometimes the other way. ${ }^{28}$ The ends of this stream are not to build Japanese industrial policy but to enable the governmental engines to aid particular corporations and their groups. A common conception of the Japanese corporation sees it as a family, with all members playing special roles that gain protection within the governance structure, and for whose ultimate power and size all family members are expected and feel constrained to work. ${ }^{29}$

These alternative conceptions of corporate purpose endure among all vital countries, including alternatives among members of the European Union and of the Union itself, despite three decades of harmonization efforts in Europe and more than a decade of harmonization pressure wrought by globalization. This suggests that redefining these goals by fiat, particularly by a foreign power, is not only doomed to fail but could backfire by reinforcing national or regional commitment to existing local conceptions.

This reality is reinforced by the variety of tools that radiate from these different purposes. The finance characteristics of these countries vary. Some rely more heavily on equity financing through public capital markets, as in the US and UK. Others rely more heavily on debt financing provided by banks, as in Germany and Japan. Others show a mixture, as in France.

Differences in corporate purpose and finance tools influence governance tools. Managers of US and UK corporations are overseen by a board of directors consisting of a mix of inside and independent directors and are headed by a CEO characteristically wielding significant and often dominant power within the corporation. A complex system of legal and market checks and balances imposes discipline on the CEO, management and board to advance the mission of delivering profits for shareholders.

Germanic corporate governance (as well as Dutch) differs most conspicuously by its twotiered board structure, a supervisory board comprised of multiple constituent groups and an underlying management operational board. Internal checks do most of the disciplining work, less market- or law-based, to advance the key mission of business continuity and survival. More participants sit at the table. On the supervisory board sit representatives of creditors, employees, managers, and shareholders. The process and structure of corporate governance is more concentrated compared to the diffusion of participants in the US/UK model. ${ }^{30}$

Although French corporate governance offers such features as dual boards, French corporate governance in practice resembles US corporate governance. ${ }^{31}$ Both produce senior executive officers possessing substantial power, a somewhat weak but potentially omnipresent 
board of directors, and shareholders, employees, and other constituents nominally furnished a variety of protections substantially through process-oriented principles such as director independence, disclosure, and the like. Labor exerts substantial influence in French power centers, including at corporations, both through unions and in work councils.

As in the US, statutes empower Japanese boards of directors to manage the corporation. Unlike the US, they actually exercise this power rather than delegating it to officers. In fact, the concept of officers as it is known in the US is unknown in Japan, for all those who would be considered officers (or senior management) in the US are on the Japanese board. The board, in turn, is split into a series of ranking hierarchies, as well as into numerous committees. The use of committees arises as a practical necessity from the large average size of Japanese boards. ${ }^{32}$

Corporate purposes, and the finance-governance-spokes attendant to them, drive different accounting rules relating to individual companies and to corporate groups. Particular differences drive enormous bottom line differences. Numerous studies indicate that the identical business performance would be measured differently in terms of profits in various European countries. For example, the same exact series of hypothetical business transactions produces profits of 89 in Germany, 100 in France, and 129 in the UK. ${ }^{33}$

These accounting figures bear an intuitive relationship to corporate purposes. Of the group, the country most devoted to profit maximization is the UK and, lo-and-behold, its accounting produces highest reported profits. Of the group, Germany exhibits the greatest interest in survival not growth, a goal consistent with relatively lower reported profits. France is in between, reflecting a country most given to sovereignty promotion rather than profit or survival alone.

The US is akin to the UK, and far different from Germany or France. ${ }^{34}$ Japan is more akin to both of the latter: in each case accounting is law and the chief objective is to comply with legal requirements often driven by tax and fiscal requirements, not necessarily to depict financial performance and condition. ${ }^{35}$ These differences in country accounting persist despite global efforts since the 1970s to produce an agreed set of international accounting standards.

A similar fragmentation besets auditing. In all vital countries, the audit is the ultimate bonding and intersection of corporate finance, corporate governance, and accounting, undergirded and reflected in the practice and purposes of the audit. All require auditor independence. Beyond the audit requirement and a shared broad general mandate for it, differing are all the other elements of corporate life: the hub of corporate purpose and the spokes of finance sources, management structure, and accounting measurements.

\section{B. Enter SOX}

It was into this diverse global corporate landscape that SOX entered. The central implication illustrated by the hub-and-spoke structure of comparative corporate systems is that the assembly is intertwined. ${ }^{36}$ A particular hub accompanies a set of suitable spokes. Hub purposes and finance structures are linked; they drive governance structures; the combination dictates disparate accounting conventions. All elements of the system are tested and evaluated in 
an audit, directly in the case of accounting and indirectly in the other areas. SOX aims at the spokes in ways that could easily be taken as threats to the hubs, a perception that explains much of the static in the world's reception to SOX.

Without cataloging all of SOX's provisions, several illustrations make the point. ${ }^{37}$ SOX establishes an audit oversight board that duplicates regulatory boards in other vital countries; ${ }^{38}$ it compels auditor independence by specifically restricting a specified list of activities resembling but not matching those restricted in other vital countries. ${ }^{39}$ Carrying more obvious capacity for international conflict, SOX codifies US norms concerning audit committees, imposing specific mandates and independence requirements differing from those of other vital countries; and requires $\mathrm{CFO} / \mathrm{CEO}$ certifications seen by other vital countries as alien on three levels: individual responsibility on the officers versus collective responsibility on the board or management; internal controls geared toward different financial reporting processes; and attestation to the globally Protean concept of a "fair presentation."

Consider more specifically SOX's provisions requiring annual officer financial certifications. ${ }^{40}$ A key issue concerns the requirement to certify that the financial statements "fairly present" a registrant's condition and results. This concept, introduced to Europe by the UK in the Fourth Directive, is a source of endless controversy in Europe, and in Japan. Though the standard has been required of non-US SEC registrants for years, including it in the officer certificates raised concerns about whether liability standards had changed. While this was also an uncertainty in the US, it carries potentially greater risks for non-US registrants outside the Anglo-American traditions.

The meaning of "fairly presents" (or in the UK "true and fair" and France the image fidele) varies throughout the world. ${ }^{41}$ If the accounts must fairly present (or be true and fair) strictly according to US norms, it is virtually impossible at present for a non-US issuer to meet the standard fully. The meanings are rooted in different traditions, with all the spokes of corporate life sustaining the differences. That can remain the case even after reconciliation with US GAAP. Until SOX, non-US SEC registrants exhibited a level of comfort with the overlap between US meanings of true and fair with local meanings. If the stakes are raised too much, the risk of error in estimating the overlap becomes too great. ${ }^{42}$

A related general issue arising under the certification requirements - as well as much of the overall philosophy of SOX - concerns internal controls and processes necessary to enable those certifications and disclosure. These vary under local rules and practices throughout the world. A mandate to certify the design and failsafe of such systems leaves ambiguity concerning exactly what controls are required. Thus failure to conform to SOX's implicit or explicit requirements increases risks to non-US issuers.

The third broad difficulty with the officer certification is the imposition of responsibility on individuals versus collectives. Boards have this responsibility elsewhere, not particular people. On the other hand, contemporary German reforms expressly shift responsibility from groups within the corporation to individual actors. A movement towards individual responsibility within corporations may be detected in Japan as well. The process is new, 
however (and bears a mark of American individualism), making compliance with individual officer certifications a slightly more risky undertaking for non-US issuers.

\section{SOX's Global Reception}

These sorts of differences formed the basis for global criticism of SOX. Reactions varied among countries. Some rightly criticized particular SOX provisions, and the SEC in most cases subsequently offered accommodations. Others criticized SOX's reach into the internal affairs of non-US corporations on principle. Most criticism suggested deeper concerns: that the norms SOX carries conflict with ultimate concepts of corporate purpose and are thus threatening. While these concerns are legitimate, they may unintentionally be exaggerated. At the same time, the US position was insensitive to these legitimate concerns. When it comes to corporate law and practice amid globalization, the US and its global neighbors all need lessons in comity.

\section{A. Public Reactions}

Facing SOX's broad reach, a group of 24 German corporations promptly and publicly petitioned the SEC for an exemption. They argued that the German system prevents the sort of accounting and other fraud perpetrated at US companies such as Enron and WorldCom that SOX's provisions expressly address. First, CEOs do not dominate firms the way they dominate US firms. Second, two boards govern, a supervisory board composed mainly of nonmanagement directors and spearheading the duty to conduct annual audits, and a management board with the operational officers. Third, the supervisory board's members include, by statutory mandate, employee representatives.

These seals in Germany's corporate governance structures raise points of practical conflict with SOX. As to governance, SOX requires all members of audit committees to be independent. But the German model's employee-populated supervisory board with audit responsibility conflicts with SOX's outlawing non-independent audit committee members. The conflicts are subtle and of two sorts, one legal and one cultural. The legal conflict arises at the level of the supervisory board, nominally the audit committee. SOX's audit committee independence rules would bar employees from serving. The cultural conflict arises because many German corporations in practice moved audit committee powers to the management board to avoid employee involvement, but management board members would likewise not qualify as independent under SOX. After much lobbying, the SEC offered accommodations to this corporate governance model under SOX. ${ }^{43}$

The most potentially acute conflict SOX poses for Germany does not concern these nuts and bolts of governance and auditing or even disclosure, but the certification requirements drilling down to "fairly presents." This challenges the methodology and goals of German accounting and, ultimately, corporate purpose. In that sense, the deeper conflicts antedate SOX and are unaffected by it. What differs, of course, is that the US is throwing its weight behind the requirement in a heightened manner, shining a spotlight on an issue German corporations have dealt with in lower key ways such as arguing that a true and fair view is produced by adhering to German bookkeeping in reporting the numbers and using footnote disclosure to explain how 
different the figures would be but for the effects of peculiar German accounting rules such as those concerning taxes and reserves. ${ }^{44}$

While the semiotic challenge and international pressure is independent of SOX, the challenge and pressure rise. And they address head-on the measurement of corporate performance which is at bottom a question of corporate purpose - a true and fair view indicates a shareholder primacy norm whereas German bookkeeping indicates a survivalist orientation. Accordingly, while SOX's detailed rules bear surface conflicts with German law, those conflicts cannot explain vociferous German objections. ${ }^{45}$ The objections run to deeper matters of corporate conception. And that battle both antedates SOX and continues in its wake.

If the German corporate voice was loudest in objecting on the merits due to substantive legal conflicts and deeper threats to ultimate corporate conceptions, the French voice was loudest in objecting in principle despite few or no conflicts but perhaps deeper distaste. ${ }^{46}$ Few SOX provisions conflict with French corporate regulation or practice. On the contrary, its overriding philosophy of audit and control, founded on principles of independence, has long been embedded in French corporate regulation and practice. ${ }^{47}$

French government leaders urged their own set of reforms, inspired by SOX or at least along similar lines. ${ }^{48}$ The parallel reform effort was in France led by Daniel Bouton, chairman of Sociéeté Générale. ${ }^{49}$ French business leaders indicated that while the US needed SOX-type reforms, the French either do not really need them or could incorporate its provisions with ease. ${ }^{50}$ And they are correct. The two systems bear critical similarities that create co-extensive pressure points, including centrally the strong-manager/weak-board syndrome. ${ }^{51}$ Even the officer certification provisions relating to fair presentations have been embraced by French multinationals in a far fuller way than compared to German multinationals.

What critics in France mostly emphasized was SOX's political power dimension: "European countries should find a stronger collective voice in setting corporate governance standards, in order to carry more weight in discussions with US standards bodies." 52 The French response to SOX does not concern SOX's detailed content, as much as the sense that its entire apparatus is geared toward profit-maximizing market oriented corporations that stand in tension with French industrial policy traditions and emerging norms in Europe - and the next subsection suggests similar truths concerning other public reactions to SOX.

British government leaders urged the US to back down, after SOX passed, fanning out with their counterparts to lobby for exemptions. ${ }^{53}$ Trade Secretary Patricia Hewitt criticized SOX as addressed to US problems and Congress for failing to think through its extra-territorial effects and impact on non-US firms. She also argued that the UK regulatory framework is stricter and better than the US version, even after SOX. British business leaders echoed such sentiments, seeing SOX as a yawn, an extra hassle, something to live with, and that British industry has no problem certifying its accounts or doing the other things SOX mandates. ${ }^{54}$

The British criticism of SOX was mainly that the US was playing an awkward game of catch up with UK norms. The criticism reaffirms a strong sense in which the UK/US model is an overlapping model. Any differences of emphasis or scope are mainly differences in which the 
US lags behind the UK. There is substantial harmony, and UK SEC registrants face few burdens in meeting SOX's demands. But they are superfluous. ${ }^{55}$

The Japanese response to SOX is difficult to gauge. Some prominent Japanese corporations publicly criticized SOX, ${ }^{56}$ at least one aborted a planned NYSE listing,${ }^{57}$ and others nodded their contentment. ${ }^{58}$ As in other countries, leading business groups spelled out the concerns in lobbying efforts before the SEC, but precise reasons are more difficult to enumerate compared to doing so for the UK, Germany or France.

A cultural chasm separates Japanese and US corporate conceptions, radiating throughout each spoke of those conceptions. Even seemingly simple provisions of SOX do not map well onto the Japanese corporate governance template. For example, SOX repeatedly uses the concept of officers, a designation ill-suited to Japanese corporate governance, where those who would be considered officers in the US are in fact board members operating through the elaborate hierarchy of committees. Post-SOX, the SEC offered accommodations that address certain of these differences. ${ }^{59}$

The European Union's reception of SOX included a blistering list of seven points of objection and produced lobbying effort seeking exemptions. ${ }^{60}$ Even so, the criticism from Brussels appeared less intense than that emanating from local European capitals, especially Paris and Frankfurt. ${ }^{61}$ Three possible explanations appear.

First, the European Union's willingness to accept some of SOX's rules may be a simple recognition of the governance sense of many of them. ${ }^{62}$ Second, SOX's threat is less acute to Brussels at the moment than to Paris and Frankfurt, simply because there are French and German SEC registrants but as yet no European corporations ("SEs") in existence let alone listed in the US. The third possibility contains both a speculation and a normative point.

Whether European Union leaders are conscious of it or not, SOX's mandates reflecting rules oriented toward advanced capital markets can be helpful to Europe as she steers her capital markets in that direction. The external imposition of internal uniformity can be a force the various European countries working with one another have failed and never may through those means be able to achieve. It creates an opportunity to generate long-sought harmony for a centralized or at least integrated European stock market, putting together disparate powerhouses in London, Paris, Frankfurt, Zurich, Milan and other capital cities. On the downside, of course, those standards are US products rather than products of international or European development.

There is no doubt that Europe is eager to integrate and deepen its public capital markets, however ${ }^{63}$ The EU steers away from imposing uniform corporate regulations on member states. ${ }^{64}$ Doing so through Directives is a cumbersome process. But some degree of uniformity will ultimately be necessary and more of it may be desirable for capital formation, capital cost reductions, and greater competitive power Union-wide. ${ }^{65}$ To the extent this must be done by Directive, prospects are not high; to the extent it can be done through securities market regulation, they are much higher. ${ }^{66}$ To the extent SOX offers a mechanism to aid the processdirectly or through rallying European member states to oppose it in favor of pan-European 
solutions - Europe may benefit, giving it a source of thrust in the endless give and take that characterizes European corporate harmonization efforts. ${ }^{67}$

Moreover, national legislatures in Europe need not fear that development of European capital market regulation will be used to impose discipline on member states, a feature of US capital markets that keeps Delaware and other competitors for state charters in check in their race to the bottom or top in chartering corporations and regulating their affairs. ${ }^{68}$ The risk of such a race in the US is a product of the US conflict of laws principle called the internal affairs doctrine. Corporations can locate and operate anywhere in the US and be governed by the corporate laws of another state entirely. Capital market discipline-through investor action and federal regulatory supervision-keeps states in check.

Europe takes a different view, holding that the law of the corporation's main place of operations or business governs (the siege social rule). ${ }^{69}$ There should be no race to the bottom through simple reincorporation to member states offering favorable charters. There is no need to develop Union-wide regulation to impose constraints on such a race. That is a selling point for harmonization efforts through capital markets. The remaining risk of a race to the bottom in Europe is continued fragmentation of her capital markets. That risk emboldens the movement towards linking European bourses, another force given potential power by the controversy over SOX.

\section{B. Reinterpreting the Public Reactions}

The discussion of France's public reaction to SOX suggested more is at stake than meets the eye. It is possible to understand the German and French reception of SOX at face value, as expressions of concern for comity, for the US pursuing global harmonization of prevalent differences in business practices unilaterally. It is possible to understand the warmer UK reception in terms of SOX's non-radical character given fundamental US-UK system comparability. Standard harmonization perspectives do not readily explain the nuanced EU and Japanese responses (and for that matter SOX's strong endorsement from such places as Brazil, Russia and Thailand). ${ }^{70}$

Explaining the variable receptions is enriched, however, by emphasizing SOX's potential effect on national corporate conceptions. With few exceptions, all SOX provisions bear conceptions of the corporation that are distinctly Anglo-American. Whatever uproar they produced in the US and the UK (or in countries with kindred systems such as Canada and Israel), at least corporate citizens in those countries can recognize their own culture in SOX's approach to the regulatory landscape.

For countries outside the Anglo-American cultural heritage, SOX is distinctly foreign. This is far more than a simple matter of conflict of laws, however. True, in certain significant cases, such as for German corporations under SOX's audit committee rules, SOX's provisions directly conflict with a corporation's home country law, making it nearly impossible to comply with both. The German ruckus in response to SOX could be understood in these terms. But something more seems at stake. 
Even in cases where substantial regulatory harmony between SOX and home country rules appear, as in France, an unmistakable cultural emblem accompanies SOX that translates poorly. A superficial explanation of simple anti-imperialism doesn't capture the depths of the French rebuke of SOX. Nor would it explain why the Japanese assessment of SOX was far less concerned with its imperialist overtones. On the contrary, Japanese law was amended during the same era SOX was adopted to expressly permit home corporations to adopt either Japanese or US-style governance systems.

A fuller explanation of the variegated global reactions to SOX emerges from addressing how it bears on the special missions designated for home corporations. US and UK companies share the goal of maximizing shareholder profits, a goal to which SOX's provisions are directed. An integral part of that goal in the UK, more so than in the US, is to promote British capital markets, another potentially powerful by-product of having companies follow US-style corporate regulation epitomized by SOX. In Japan, the penultimate corporate goal is expanding power, measured by factors such as corporate size and market share. Adoption or use of SOX-style provisions with the deeper characteristics of the US model may be seen as facilitating that goal, directly or in comparison with other nations.

The penultimate goal of German corporations is survival, a feat threatened by imposition of non-German corporate norms, a direct challenge to survival of corporate Germany. In France, corporate orientation supports sovereignty enhancement, of boosting the French state and its constituent parts, corporate and personal. Externally imposed mandates threaten that purpose, a deeper affront compared to territorial-regulatory integrity concerning the detailed matters SOX addresses. The EU's emergent community conception of the corporation seems surprisingly like that in Japan, designating competitive power as the corporate mission, a component of the bloc's quest for economic might. ${ }^{71}$

SOX's thrust is on audit and control, tools bearing resemblance in description, form, and structure in all vital countries. But since audit and control address, test, and verify substantially different underlying accounting data driven by finance and governance peculiarities, the audit signifies different pressure points. It could be that changes in audit and control drive changes in the other elements such as corporate purpose and governance and this is what SOX's non-US foes fear. The harmonization and convergence efforts to date suggest, however, that even substantial changes in audit and control can be rendered sufficiently capacious to leave these other elements undisturbed. Such is the case with the true and fair view requirement, for example.

Changes at the hub are the only changes that matter, in this view. But this is far from obvious, so changes in the spokes - especially of auditing and control - that produce potential impacts on penultimate goals will drive global discourse in responding to externally-driven standards and rules. SOX contains a plethora of these, mostly codifications of US practices, and most of which are the sorts of tools used in all vital and many other countries though with different emphasis and to different ends.

As a result of these potent forces, national reactions are likely to be geared to SOX's influence on corporate purpose rather than to SOX's detailed provisions that may conflict with 
local standards. This remains true even if the likelihood is slight that those detailed provisions can dent such ultimate purposes. The history of harmonization efforts amid globalization suggests this is the case. The most harmonized area is accounting, and it faces obstacles at every turn. The prospects for auditing and control harmony forged via SOX are not much greater.

\section{Imprecision in the "No-Scandal-Here" Criticism}

A chorus of global complaints against SOX held that its reforms were necessary to fix a leaky US system beset by scandal but that these were uniquely US problems. ${ }^{72}$ A test of the premises of this argument reinforces the thesis that global reactions to SOX were louder than content warranted, but still reasonable given possible threats to conceptions of ultimate corporate purpose.

The "no-scandal-here" criticism is too blunt. Problems of corporate malfeasance are everywhere, though they concern different things. Controls, processes and rules exist everywhere and can be broken everywhere. Some of these rules look the same, but they are trying to control different forms of deviance. To this extent, the "no-scandal-here" criticism misses the mark but carries the hidden truth that nipping at recurring scandals calls for tailored tools. This makes SOX even more objectionable, not because scandals are absent elsewhere but because of scandals' local flavor.

The US goal of profit-making for shareholders entails rules to control agency costs of siphoning off corporate assets in derogation of their claims (or those of creditors in the case of insolvency where corporate mission shifts). ${ }^{73}$ The German goal of assuring survival means taking all prudent steps to protect the entity as a whole, broadly conceived. This entails rules to control for policies or practices that push towards bankruptcy (or even unwanted takeover, as the recent German response to the rejected $13^{\text {th }}$ Directive indicates) ${ }^{74}$ France bears the same distinction, reflected in its special accounting laws governing troubled companies. In France and Japan relationships with the state play a more intimate role in business, producing greater possibilities for deviations from norms governing such relationships.

The global history of corporate chicanery shows that no country or system is free of scandals. ${ }^{75}$ Start with Germany. Germany had its share of accounting scandals dovetailing with those precipitating SOX. The upshot there was the expansion of the powers of its financial sector regulator, the BAFin, with new powers of an accounting police functionally equivalent to various accounting and enforcement arms of the SEC. ${ }^{76}$ On the agenda were proposals to hold managers directly liable, an innovation in Germany, where liability for covering up and misleading reports previously lay with the company as a whole. ${ }^{77}$

Germany's version of the US's Enron-era frauds was led by the regional bank Bankgesellschaft Berlin, which appears to have falsified its accounts for years. ${ }^{78}$ The scandal began to emerge, and regulators to crack down, before Enron erupted in the US. There were many runners-up. ${ }^{79} \quad$ Germany's high-tech market forged during the global bubble of the late 1990s shut down as of 2003 after disclosure of a series of accounting and governance duplicity. ${ }^{80}$ For example, ComRoad purported to develop traffic-navigation technology for the automotive industry. The start-up instead manufactured sales, purporting to comply with German 
bookkeeping, sporting a market cap of US\$1 billion, eventually imploding, and landing its founder a seven-year prison term. ${ }^{81}$

The cause celbre in France of the 1990s was the major corporate scandal at Credit Lyonnais. CEO Jean-Yves Haberer overextended the state-owned bank's risk portfolio, investing in ill-fated projects such as East London's Canary Wharf development and cashstarved MGM movie studio. Weak controls produced losses at the bank of some $\$ 2$ billion in 1994 rising to $\$ 17$ billion in 1997 . The French Ministry of Finance put the bank in functional receivership. Judicial investigations ensued, examining whether French government officials concealed the bank's problems when it published its financial reports. Top executives faced criminal charges for their role in the debacle. ${ }^{82}$

During the era provoking SOX, France suffered from a corporate crisis known there as France's Enron: the case of Vivendi Universal SA. CEO Jean-Marie Messier transformed a modest water utility company into a multinational media empire rivaling AOL-Time Warner and News Corporation, only to bring the company to the brink of bankruptcy due to accounting aggression, disclosure deception, and supine supervision. Mirroring US governance crises of the era, Messier hid the company's financial turmoil from Vivendi's board and shareholders for many months. When discovered, it was too late to extricate Vivendi from the disaster.

Europe as a political entity faced analogous weaknesses. In formulating the EU budget, accounting controls turned out to be unreliable. ${ }^{83}$ In Summer 2002, as corporate scandals reached crescendo in the US, reports leaked a paper by the EU's court of auditors saying the EU's $€ 98$ billion budget is "insecure and unreliable." ${ }^{\prime 84}$ The reports vindicated the position taken earlier by the EU's former chief accountant, who was ousted for her criticism and her refusal to sign the EU's 2001 accounts. ${ }^{85}$ The reports and earlier criticism by the EU's court of auditors declared that "no account has been taken of generally accepted accounting standards, mainly double-entry book-keeping" and final data "may be inconsistent, so that a single line of expenditure can have two different values." ${ }^{86}$ Also "Controls in the system were inadequate" so that it was impossible to "present reliable accounting data on the amounts advanced to third parties." ${ }^{, 87}$

Looking back a few decades in Japan, consider the global scandals involving US companies bribing foreign officials during the 1960s and 1970s. In Japan, this became known as the Lockheed scandal and led directly to the overthrow of its government. The resulting reforms in the US were the Foreign Corrupt Practices Act; ${ }^{88}$ in Japan, the Lockheed scandal resulted in reforms to make directors more accountable to the whole board and strengthening the whole board's supervisory authority. ${ }^{89}$ The goal was to transform Japanese boards from hollow shells controlled by powerful presidents. ${ }^{90}$ These scandals were independent of the US influence, as corporate Japan suffered accounting scandals among several large public corporations in late 1964 and early 1965, resulting in bankruptcies and provoking regulatory responses from the Tokyo and Osaka stock exchanges and from the Minister of Finance. ${ }^{91}$

More recently, Japanese business took a black eye in the scandals involving Snow Brand Milk. The food maker's milk products caused mass food poisoning in 2000 revealing poor internal controls and lax hygiene standards. A year later fraud was discovered at its meat 
subsidiary, with 30 tons of imported beef products deliberately mislabeled in order to win government subsidies paid on domestic beef following Japanese scares that imported beef carried "mad cow" disease. In November 2002, five employees were sentenced to jail by a Japanese court for their role in the scam. ${ }^{92}$

Other major countries witnessed corporate scandals during the same period, ranging from Belgium $^{93}$ and Switzerland ${ }^{94}$ to China. ${ }^{95}$ According to the OECD, the Asian financial crisis of 1998 was caused in part by weaknesses in corporate governance at some Asian companies. ${ }^{96}$

While the no-scandal-here argument is thus false, this does not necessarily mean that the proper fixes to any given country's or bloc's weaknesses are those contained in SOX. On the contrary, problems arise in different ways and due to different reasons. Different solutions may therefore be indicated. But this insight renders the objection more significant as a matter of US policy, not less. The frequency of the "no-scandal-here" argument shows foreign upset beyond SOX's content, underscoring the need for greater sensitivity and diplomacy in formulating US corporate regulations affecting corporations around the world.

\section{From Convergence to Comity}

A common theme of all comparative law is the prospect of pressure toward convergence. Debate centers on the role law plays in culture. At polar extremes one can see law as a driver of culture and legal reform conducting social change; at the other end law is but a factor in culture, an expression of culture, the surface of culture, so that legal change may influence culture but cannot control it. ${ }^{97}$

\section{A. The State of Convergence as a State of Mind}

In comparative corporate law, the convergence thesis is tested in terms of empirical observations about both legal change and consequent or concomitant social change. In this line of study, custom specifies that the US/UK model exhibits an outward orientation from the corporation, with a focus on shareholder value and financial returns, while Germany, France and Japan are more insider-oriented with a collectivist and communitarian bent.

Substantial evidence can be marshaled to support a convergence thesis among these stances. The issue then is convergence towards what, one of these models, or a hybrid. Evidence supporting convergence on lines of a US-UK model would include inclinations toward more contract- and market-based methods. ${ }^{98}$ Seen this way, the evidence is strong.

In Germany: unions and workers have lost clout; regulations are disappearing; banks are divesting equity positions and diversifying loan positions; enhanced standards for financial disclosure are adopted; new supervisory authority for securities markets is established; companies increasingly list shares abroad, in Anglo-American systems. ${ }^{99}$ In France: shareholders are demanding and getting more rights; regulations are limiting multiple directorships; hostile takeovers have appeared. ${ }^{100}$ In Japan: keiretsu firms have begun to sell some cross-shareholdings; lifetime employment is facing debate and decline; and there has been 
a rise in Japanese corporations taking US or UK listings (now amounting to 34\% of Tokyo's 100 largest market cap companies listed on a UK/US market). ${ }^{101}$

This view is intended to counter arguments that corporate governance systems are products of various historical, political and economic forces. ${ }^{102}$ Those forces mean systems are not just marching towards a competitive convergence in equilibrium. They are path dependent, implying one cannot declare a winner. The contractairan view sees clear evidence that the $\mathrm{US} / \mathrm{UK}$ model is the best and the one all others are heading toward.

But is this so clear? The evidence marshaled can all be admitted and credited. None of it changes the hub. The evidence suggests some movement to contractarian models as a spoke. Contract is a capacious instrument. It can be used to achieve a variety of penultimate goals, from shareholder-centric profit generation, to corporate survival, to sovereign-enhancement, to power and expansion. The capacity of contract is co-extensive with the capacity of the mechanical tools Europe has used to promote the true-and-fair view and to expand intra-continental auditing practices. The same is true of SOX's rules relating to governance and auditing. All can be used as administrative mechanisms to promote corporate accountability, while to what ends accountability must be faithful vary sharply.

A stronger version of the US-UK convergence story remains possible, inspired by a strict brand of law and economics devoted to markets exclusively as the least dangerous means of supervising the production and organization of economic activity. In this story for comparative corporate law, emphasis is on the universal and abstract rather than the unique and particular. Conceptions of the good are ultimate and all peoples will eventually see it the same way. Getting there is a haphazard and rough road toward a smoother paved convergence. For legal comparativists, the chief engine driving passengers on this track is law. Legal change-toward the looser, market-based and profit-oriented light at the end of the road-paves the way.

Signposts on this road are harder to see. Immediate contrary evidence is precisely the reaction globally against embracing SOX, with its gears trained on profit maximizing corporations, managed, measured and audited using that baseline. Even in Europe, as already noted, longstanding convergence efforts show as much resistance as motion-the EU's philosophy moved from alacrity for unification to settling for harmonization at the level of general abstract principles filled in with vastly different underlying particularity. ${ }^{103}$

Developments suggest caution about the other extreme just as well. Divergence theorists maintain excessively that resistance is immutable. But change is likewise evident. Some convergence is brewing. Strong evidence includes IASC's articulation of such powerful and potentially transcendent accounting concepts as cash flow statements and segment reporting. ${ }^{104}$ The concept of cultural essentialism is as out of whack with observation and common sense as the devotees of the road to Nirvana. It is a cliché to note that it means little to observe that natives speak French in France, German in Germany and English in England. It is useful to note that they virtually all speak in English, however. Dynamism prevails.

The difference between economic convergites and cultural divergites is the latter allows for too little dynamism and the former for too much of one kind of dynamism. The evidence 
suggests that the reality lies in between. Legal dynamism is iterative. ${ }^{105}$ Just how the iteration operates will remain as hidden as the issue of the causation of hub-and-spoke characteristics of existing models. One clear consequence is some subordination of mere conflict of law matters. Just as the key problems with SOX vis-à-vis non-US issuers and auditors is not chiefly about conflict of laws, the iterative operation of global comparative corporate governance will rest on deeper philosophical differences over the purposes of the corporation than superficial conflicts in laws (or similarities for that matter).

Distinctions between domestic and foreign law become less important than questions about domestic and foreign practice. ${ }^{106}$ Evidence of these iterative elements can be identified. The evidence marshaled in support of expanding use of contract methods in civil law countries is matched by some evidence of increasing resort to fiduciary obligation and sensitivity to constituents other than shareholders in the US/UK model. ${ }^{107}$ But it remains the case that what matters are how those moves play out in operation, how US/UK directors embrace heightened standards of obligation to attend first to interests other than their own, such as shareholders, and second, to interests of constituencies other than themselves and shareholders. ${ }^{108}$

Corporations are creatures not only of law but of culture. Global corporate governance, influenced or not by SOX, will remain distinctive, comparative, and characterized by different hubs, even as the spokes may on the surface converge. Even those spokes are unlikely to exhibit uniform descriptions. Law seems a less powerful force in that regard than markets. The finance spoke is the one most likely to undergo change; of the spokes, it has undergone greatest change. Examples among the vital countries include increasing cross-listings, German bank diversification, and French industrial privatization. Examples among countries in the global periphery are precisely the enormous increase in the number and size of foreign SEC registrants during the 1990s. ${ }^{109}$

The contending scholarly stories of convergence and path dependence are thus both partly true. Convergence pressure exists and markets increasingly play a critical role. But divergence persists, with other tools remaining vital. The road to markets may be the only road to take. But it is full of potholes. The US leads the world down that road; the divergenceconvergence debate moves to the roadside. What matters more is how that leadership is exercised. The mechanisms of US corporate regulation determine the rules of the game and the shape of convergence and its success. ${ }^{110}$ This makes the US regulation of corporations a matter of international relations as a tool to influence the sustained spread of liberalism throughout the world.

\section{B. The Road to Comity}

The convergence case is strongest in its normative sense. Free market capitalism is the most effective and only demonstrated method of sustaining growth and improving living standards. The American model requires no apology and US national interests must be staked and defended. The risk is that uncontained, its collateral effects can produce a backlash that will undermine its enormous promise. Demanding compliance with it by other states or companies domiciled in those states is neither necessary nor fruitful to meet these objectives. This is the

lesson from the $19^{\text {th }}$ century's laissez-faire extremism that gave rise to Marxism. ${ }^{111}$ The move to 
global markets as a matter of economics must be matched by local politics that smooth the process. That smoothness must begin with political comity when the internal regulation is imposed by another country.

With legislative moves such as SOX, this meant what the SEC did but too late: offering exemptions to SEC registrants already possessing requisite safeguards modeled locally. The big mistake of SOX was not to attend to those matters as part of the legislative process. ${ }^{112}$ It was a case of domestic political pressures blinding lawmakers to important matters of international relations. It was a wasted opportunity to exhibit comity in the exercise of US power on a matter that would cost the US little. ${ }^{113}$

Nothing in law requires any US consultation with counterparts abroad when passing legislation such as SOX. Nor is there any particular reason to consult issuers and auditors in foreign states, just as there is no obligation to conduct such outreach applies to domestic corporations.

As to members of Congress, moreover, ordinarily lobbyists would come to them to opine and influence, not the other way around. Lobbyists on behalf of foreign interests did seek to influence members of Congress concerning SOX, ranging from Commissioners of the European Union to a group of CEOs of German SEC registrants. The Committee hearings, however, eschewed this international relations dimension of the legislation. ${ }^{114}$

Within the executive branch, moreover, when legislation poses extraterritorial consequences and is strongly influenced by a US regulatory body, that body would ordinarily be expected to venture some outreach to its affected regulatory counterparts. In the case of SOX, this would mean the SEC reaching out to the London Stock Exchange, the UK's Financial Services Authority, the Federation of European Securities Exchanges, European ministers, international accounting bodies, or the 100-nation International Organization of Securities Commissions (IOSCO). ${ }^{115}$

A few special features of SOX's context rendered the outreach particularly important. First, the speed with which SOX was brought; second, the impaired ability of non-U S regulatory agencies to seek or obtain a formal hearing through the legislative process; and third the repeated characterizations made by SOX's sponsors and by commentators that SOX carried "sweeping" and "far-reaching" effects. While these statements were exaggerated as far as US registrants are concerned, they are more accurate as applied to non-US issuers.

On the other hand, despite globalization, US securities regulation's traditional dedication to investor protection must not be undermined. Congress and the SEC must conduct vigilant oversight of US capital markets and modify the regulatory environment in accordance with institutional judgments concerning investor protection goals. After all, 90\% of SEC registrants are US entities, for which only that supervisory framework is relevant in the US. Whatever one's views on the prudence or scope of SOX, Congress and the SEC properly exercised their prerogatives and mandates in responding to felt needs for US capital market regulation to protect investors. $^{116}$ 
Injecting an international relations viewpoint into the process would not require much, however. It would call for Congressional committee hearings to include examination of the global effects of US corporate legislation. In the case of SOX, beyond this it need not change anything Congress or the SEC did with respect to those registrants. To recognize this dimension would have meant simply doing before SOX became effective for non-US SEC registrants exactly what the SEC belatedly did after enactment. It took several quarters to do so, but the SEC eventually gave hearings to foreign representatives and exemptions from various requirements of SOX for non-US issuers for whom those elements were unsuitable from the issuer's viewpoint and unnecessary to achieve the US goal of investor protection.

These steps should be taken beforehand. This can be accomplished with no other change in the legislative process (apart from committee examination of the collateral effects). In the case of SOX, exactly the same process would have been followed, except an additional provision in the Act would have rendered it ineffective as to non-US SEC registrants. The provision could stay effectiveness indefinitely or suspend it until either the SEC elects to declare it effective or until Congress does so following reports from the SEC. ${ }^{117}$

The determination to stay or impose effectiveness would depend on a finding that all or some non-US registrants undergo adequate comparable regulatory supervision in their home country so that US investor protection goals are deemed satisfied by compliance. ${ }^{118}$ This determination could be made on a country-by-country basis for most companies ("favored nations") or for particular companies operating in countries that otherwise lack requisite controls but which voluntarily comply with specified international standards ("world class companies"). ${ }^{119}$ The "favored nation" approach would have the virtue of encouraging local corporations concerned with dual regulation in the US and at home to promote home requirements that meet requisite US standards. The key international relations benefit of such a measure is the result creates a measure of voluntary compliance compared to that generated by unilateral fiat such as SOX.

The favored nation approach would also neutralize any risks of US corporations pursuing forum shopping as a way to benefit from temporary or permanent stays of regulatory effectiveness. The minor risk would remain that US corporations could still shop for jurisdictions that while qualifying as recognized foreign jurisdictions remain more attractive for idiosyncratic reasons. The solution to prevent this is simply to develop the federal equivalent of the pseudo-foreign corporation rules of some states (such as California or New York) or the siege social rule of Europe. Nominal incorporation in a foreign state would be ignored for corporations that are functionally US corporations. Measuring this functionality would be done by similar tests, including headquarters location, employee or shareholder or base, or history (for example any company having been created in a US jurisdiction or existing as one during the prior five years would be treated as a domestic corporation without regard to its country of incorporation).

\section{Conclusion}

SOX shook the corporate world, far beyond US borders. It did so at a time when global liberalism has strong chances for ascendancy but also faces great risks of backlash that thwarts 
its spread. The risks are greatest in the corners of the world facing the greatest challengesstarting with Africa, then Asia, then Latin America. As to the US's best friends - starting with the UK but extending across Europe-SOX comes amid formulations of the most profound expression of European identity in corporate law, the formation of the SE.

The identity of SE companies is yet undefined by their governance, finance, accounting, and auditing attributes. They will be endowed with US versions, European versions, or the versions of particular European states, or perhaps pan-Atlantic versions. The clearest sense in which an Atlantic US-European partnership operates in corporate affairs is a pan-Atlantic complexion. Bullying European companies with a US complexion overlooks this important opportunity for shaping this partnership.

On the other hand it is not too late. The legislation is not as sweeping as the rhetoric accompanying it advertised. True, for non-US issuers, SOX imposes alien forms. In that sense SOX fails as it reflects the worst of prevalent US international relations formulation, in which the US Congress imposes itself unnecessarily on the US's closest allies. ${ }^{120}$ The world's unipolar power owes its friends respect, particularly friends whose own history is marked by global preeminence. As for the global upset SOX caused, leaders of other countries should appreciate - as many clearly do, in each of the vital countries and elsewhere - the US domestic pressures and need to respond to weaknesses in corporate governance and accounting systems in the US. It is a two-way street.

US corporate scandals will recur. SOX will not stop that. When they do, Congress and the SEC ought to embrace a recognized institutional structure in which reform laws are automatically inapplicable to non-US issuers until and unless the SEC renders them applicable. Non-US issuers would be assured of getting a fair and up-front shake in the regulatory process. The US instantly benefits from the expression of comity it extends. Needed extensions of the regulations can be assessed in due course by the SEC.

The US may be the host of the party and can certainly invite who it wishes and lay down the etiquette. But part of being a good host is recognizing the right guest list and treating guests with respect. Taking these steps is at bottom a far more common-sense approach than the arrogant hue of SOX, and ultimately far simpler and inexpensive than the very complicated process the SEC was sent through in SOX's choppy global wake. ${ }^{121}$ 
${ }^{1}$ Corporations from 59 non-US countries are registered with the Securities and Exchange Commission, and 24 of these countries boast at least 10 such companies. SEC Annual Report (as of December 31, 2001). In 1990, 434 foreign companies were SEC registrants. See SEC 1999 Annual Report, available at http://www.sec.gov/about/gpra1999-2000.shtml\#glob. Throughout this Article the term non-US issuer is used to refer to the technical label foreign private issuers given in US securities law jurisprudence. This is both because of the relativity of the concept of foreign, this journal's publication location and audience, and because it sounds better anyway.

${ }^{2}$ Public Company Accounting Reform and Investor Protection Act of 2002, 107 Pub. L. No. 204, 116 Stat. 745 (popularly known in the US as the Sarbanes Oxley Act and abroad as "SOX").

${ }^{3}$ SOX is not the first Act of Congress addressing corporate governance carrying an international relations dimension, but it is the most significant by far. Others include the Foreign Corrupt Practices Act of 1977. Pub. L. No. 95-213, 91 Stat. 1494, as amended by Title V of the Omnibus Trade \& Competitiveness Act of 1988, Pub. L. No. 100-418, 5001-03, 102 Stat. 1415, 1415-25 (codified as amended at 15 U.S.C. $\S \S 78 \mathrm{~m}(\mathrm{~b})(2), 78 \mathrm{~m}(\mathrm{~b})(3), 78 \mathrm{dd}-1,78 \mathrm{dd}-2,78 \mathrm{ff}$ (1994)) and, in certain applications, the RICO statute, 18 U.S.C. $§ 1961$ et. seq.

${ }^{4}$ E.g., Elisabeth Bumiller, Bush Signs Bill Aimed at Fraud In Corporations, N.Y. TIMES (July 31, 2002) (on signing SOX, President George W. Bush said it boasted "the most farreaching reforms of American business practices since the time of Franklin Delano Roosevelt.").

5 See Lawrence A. Cunningham, The Sarbanes-Oxley Yawn: Heavy Rhetoric, Light Reform (And It Might Just Work), 37 U. CONN. L. REV. 915 (2003); see also Larry E. Ribstein, Markets vs. Regulatory Responses to Corporate Fraud: A Critique of Sarbanes-Oxley of 2002, 28 J. CoRP. L. 1 (2002); Robert W. Hamilton, The Crisis in Corporate Governance: 2002 Style, 40 Hous. L. REV. 1 (2003).

6 E.g., Adrian Michaels, SEC Bows to Foreign Pressure On Company Laws, FIN. T. (Jan. 9, 2003); Adrian Michaels, SEC Proves Its Mettle with Move on Foreign Companies, FIN. T. (Jan. 9, 2003).

${ }^{7}$ The Pitt and the Pendulum: SEC Must Help Foreign Issuers through Legal Minefield, FIN. T. (Oct. 11, 2002).

8 See Christopher Nobes \& RoBert PARKer, COMPARATIVE InTERnATIONAL ACCOUNTING $\left(5^{\text {th }}\right.$ ed. 1998), at 11 (designating leading countries as "vital" to harmonization of financial reporting according to degree of national accounting and economic significance).

${ }^{9}$ Every country in Western Europe and increasing numbers from Eastern Europe are home to SEC registrants. Registered with the SEC are 143 UK companies, 36 French companies, and 31 German companies. These companies collectively represent substantial economic value, with market capitalizations aggregating US\$1.2 trillion for the UK, US\$326 
billion for France, and US\$287 billion for Germany. SEC registrants from Eastern Europe countries include Poland (2), Czech Republic (1), Hungary (1) and Slovak Republic (1). Other notable European countries with SEC registrants include Ireland (17), Norway (10) and Luxembourg (10). The Netherlands (43) boasts among the greatest number of foreign private SEC registrants (behind only Canada, the UK and Israel).

While the number of companies directly affected by SOX compared to the number of extant companies in each country is small (as it is within the US), the directly affected companies are large and leaders in their home countries. For example, among SEC registrants from the UK are: Barclays, British Air, Cadbury-Schweppes, and GlaxoSmithKline; from Germany: BASF, Bayer, Celanese, SAP, Schering, and Siemens; and from France: Alcatel, AXA, Lafarge, RhonePoulenc, TotalFina, and Vivendi. Other noted European names include: from The Netherlands, ING, KLM, Phillips, Reed Elsevier, Royal Dutch and Unilever; from Italy, Fiat; and from Finland, Nokia.

${ }^{10}$ Every major economic power in Asia and the Pacific is home to SEC registrants. Thirty Japanese public companies (of some 1400 listed in Tokyo) are SEC registrants, boasting a total market capitalization of US\$420 billion. SEC registrants now hale from numerous nonJapanese Asian countries, including India (12), China (11), Korea (8), Indonesia (7) and Russia (4). Australia and Japan both doubled their number of New York Stock Exchange listings during the 1990s rising from 5 and 8 , respectively, to 10 and 16.

11 Canada is home to 200 SEC registrants, totaling US\$310 billion in market capitalization. The number of Canadian companies listed on the New York Stock Exchange increased five-fold during the 1990s (from 15 to 74). It has the largest number of foreign SEC registrants among nations. Latin American countries together represent nearly 200 SEC registrants, including from Mexico (41), Brazil (37), Chile (27), Argentina (25) and Colombia (4).

12 SEC registrants include some companies based in the Middle East and Africa, including 91 from Israel, 5 from South Africa, and one each from Ghana, Liberia, and Turkey (for now at least not included in Europe).

${ }^{13}$ Christopher Nobes \& Robert Parker, Comparative International Accounting ( $5^{\text {th }}$ ed. 1998), at 6.

${ }^{14}$ See Joseph E. Stiglitz, Globalization And Its Discontents (2002), at 9-10 (noting broader conception of globalization as the "closer integration of the countries and peoples of the world" driven by cheaper transportation and communication that facilitates resource flows across borders but emphasizing that it "is powerfully driven by international corporations").

${ }^{15}$ E.g., Adrian Michaels, SEC Bows to Foreign Pressure On Company Laws, FIN. T. (Jan. 9, 2003); Adrian Michaels, SEC Proves Its Mettle with Move on Foreign Companies, FIn. T. (Jan. 9, 2003). For example, periodic reports concerning such matters as waivers of codes of 
ethics must be reported under SOX and implementing SEC rules in Reports on Form 8-K, but for non-US issuers these may be reported either in the annual report or on the company's Web site.

16 There is nevertheless a substantial comparative corporate governance literature on certain countries in addition to Japan, including China and Russia. E.g., Cindy A. Schipani \& Junhai Liu, Corporate Governance in China: Then and Now, 2002 ColuM. BuS. L. REV. 1; Joaquin F. Matias, From Work-units to Corporations: The Role of Chinese Corporate Governance in a Transitional Market Economy, 12 N.Y. INT'L L. REV. 1 (1999); Richard P. Cunningham, Jr., Corporate Governance and Foreign Investment Nightmares in Russia: A Case Study of Unified Energy Systems, 42 VA. J. INT'L L. 889 (2002); Gregory Wolk, Corporate Governance Reform in Russia: The Effectiveness of the 1996 Russian Company Law, PAC. RIM L. \& Policy J. 219 (1999); Bernard S. Black, et al., Russian Privatization and Corporate Governance: What Went Wrong?, 52 STAN. L. REV. 1731 (2000).

${ }^{17}$ See Henry A. Kissinger, Does America NeEd A Foreign Policy? (2002), at 84.

18 Id., at 87.

19 Id.; see also AMY CHUA, WORLd ON Fire: How EXPORTING FreE MARKET DEMOCRACY BREEDS ETHNIC HATRED AND GLOBAL INSTABILITY (2002) (noting how ethnic majorities shut out by market-dominant minorities may incline to vote against politicians who promote liberal states in favor of extremist dictators promising to protect them from markets and democracy).

${ }^{20}$ Globalization has erased economic borders and reoriented political ones. The economic power of the nation state has eroded while its political power endures. See John O. McGinnis, et. al., The Decline of the Nation State and its Effect on Constitutional and International Economic Law, 18 CARDOZO L. REV. 903 (1996). States seek to recover economic power by combining political power. The leading examples are the EU, Mercosur, and the Association of Southeast Asian Nations (ASEAN), designed to compete with Japan (and China).

${ }^{21}$ Stiglitz, supra, at 55-59, 69.

${ }^{22}$ Kissinger, supra at 215-216 ("Only a very few nations have ever managed to combine conservative fiscal and monetary policy, government intervention through regulation rather than ownership or control, deregulation of financial institutions, encouragement of flexible labor markets, and a widely accepted and transparent legal framework.").

23 See Katsuhito Iwai, Persons, Things and Corporations: The Corporate Personality Controversy and Comparative Corporate Governance, 47 AM. J. CoMP. L. 583, 592-612 (1999) ("Capitalism differs widely from country to country;" it is most marked in differing views of the "purpose" of the "public corporation in society"). The author reports a survey of management goals held by managers of US and Japanese corporate managers (and a mix of European companies where results were blurred because of not distinguishing among countries). US managers put return on investment at the top (78.1\%) while Japanese management put expansion 
at the top $(60.8 \%)$. The data reveal the contrast between US shareholder capitalism calling for maximizing returns to shareholders and Japan's corporate capitalism with a view toward power.

${ }^{24}$ Cf. Jonathan Charkham, KeEping Good Company (1994), at 10 (reporting study contrasting ranking of top professions by UK and German managers, with German managers ranking civil and mechanical engineering among the top five while UK managers ranked them among the bottom five).

${ }^{25} I d$., at 119 (noting that "the French sense of la politique does not draw a clear boundary between government and industry" and that in France there is "the brooding presence of the idea of the State, 'la France"').

26 See Paul Raynes, breakingviews.com (Sept. 24, 2002) (in France "a tiny club of enarques and polytechniciens still dominate the financial scene"); see also CHARKHAM, supra, at 122 (France's elite all attend "the grandes ecoles, particularly the Polytechnique, the Ecole normale and Ecoles des mines andes pont et chausses . . . [which] produce a cadre with a uniform set of values, dedicated to the nation" constituting a "permanent oligarchy" from "a relatively narrow stratum of French society, the upper middle class, much intermarried").

${ }^{27}$ CHARKHAM, supra, at 73 (power, market share, safety and growth all take precedence over profit in Japan corporate life); $c f$. Takeo Hoshi, Japanese Corporate Governance as a System (ch.11 in COMPARATIVE Corporate GOVERnANCE: THE STATE OF THE ART AND EMERging RESEARCH, 847) (KLAUs J. Hopt et al., eds. 1998) ("Like France, the Japanese government has been very actively influencing private business.").

${ }^{28}$ See Hoshi, supra (noting the practice of "amakudari," of retired government officials joining private company boards; the phrase translates as "descent from heaven"); CHARKHAM, supra, at 95.

${ }^{29}$ See Yoshiro Miwa, The Economics of Corporate Governance in Japan (in HopT, et al., supra, at 877) ("In most large Japanese firms, the controlling group is the body of employees.").

${ }^{30}$ Germany published a new corporate governance code in February 2002, constituting a codification and condensation of existing German statutory law concerning corporate regulation. GERMAN CORPORATE GOVERNANCE CODE (Feb. 26, 2002) (convenience translation in English, available at www.corporate-governnace-code.de). It expresses the view that the two-tiered board is functionally equivalent to the single-tiered board due to the cooperation and interaction between the two tiers within German corporations, concluding that "both systems are equally successful." Id., at 1; 4-5. It indicates that German accounting adheres to the true and fair view. $I d$., at 2 . It also indicates that the supervisory board is to form an audit committee, bearing duties akin to those of audit committees in the US, at 5, and gives the supervisory board the duty to oversee the audit and assure auditor independence or disclose relationships that could impair it. Id., at 12. While not binding as a statute, a subsequent statute requires German companies annually to disclose whether they comply with the code. GERMAN STOCK CORPORATION ACT, Sec. 161 (Aktiengesetz, SCA) (July 2002). 
${ }^{31}$ Since 1966, French law has authorized French companies to opt for a dual board, along the German model with employee representatives on the supervisory board, but few French companies have opted for it. See John Bell, SophiE Boyron \& SimON Whitaker, Principles OF FRENCH LAW (1998), at 445-49.

${ }^{32}$ See generally, Christopher Lee Heftelo, Corporate Governance in Japan: The Position of Shareholders in Publicly Held Corporations, 5 HAW. L. REV. 135 (1983).

33 CHARKHAM, supra, at 31 (reporting speech by Paul Rutterman, Ernst \& Young, at Oxford University in 1992). Other countries (and profits) reported were Spain (88), Holland (94), and Italy (117).

34 See Eric M. Sherbet, Bridging the GAAP: Accounting Standards for Foreign SEC Registrants, 29 Int'l L. 875, 885 (1995). Several years before it merged with Chrysler, DaimlerBenz sought a listing in the US. As a condition - in a spirit SOX follows - the SEC and the New York Stock Exchange required it to reconcile its German financial statements with US GAAP. One of numerous major differences dealt with accumulated reserves Daimler had built up in prior years and reported as income in the year of the application. Those reserves aggregated US\$2.4 billion and enabled the company to report German bookkeeping income of US\$346 million for 1993. Translated into US GAAP - not permitting such reserves - the company reported a loss of US\$1 billion

35 Donald E. Kieso, et AL., Intermediate Accounting $\left(10^{\text {th }}\right.$ ed. 2001), at 5 . See Wolfgang Ballwieser, Germany: Individual Accounts, in 2 DIETER ORDELHEIDE \& KPMG, TRANSNATIONAL ACCOUNTING (2d ed. 2001), at 1223 ("Another factor to be reckoned with is the close connection between commercial accounting and tax accounting. The profit stated in commercial accounts is usually the same as profit for tax purposes.").

Accounting and tax law are closely linked in France, though they are distinct bodies of law. French corporate tax returns include the balance sheet and income statement. Gilbert Gelard, France: Individual Accounts, in 2 Dieter OrdelHeide \& KPMG, TransNAtional ACCOUNTING (2d ed. 2001), at 1019 ff. Of course, tax laws everywhere influence accounting rules but the nexus is closer in France and Germany compared to the US and the UK. See DAVID Alexander \& Simon Archer, EdS., Miller European ACCOUnting Guide (3d ed. 1998), at 8.

${ }^{36}$ See William W. Bratton \& Joseph A. McCahery, Comparative Corporate Governance and the Theory of the Firm: The Case Against Global Cross Reference, 38 CoLUM. J. TRANSNAT'L L. 213 (1999).

37 For a full catalogue and critique, see Cunningham, The Sarbanes-Oxley Yawn, supra.

38 SOX's most significant provisions create a US-based and composed auditing oversight board with jurisdiction to supervise, regulate and discipline auditors based anywhere in the world attesting to financial statements of SEC registrants. The body will be funded by public company shareholders, not the auditing profession. 
${ }^{39}$ To enhance the independence of individual auditors as opposed to audit firms, SOX requires auditors to rotate lead and reviewing partners so that neither role is performed by the same accountant for the same company for more than five consecutive years. As shown in Part II, the approach to this subject differs among the vital countries-and reasonable people could disagree about the optimal details. Contrasting illustrations are France, which requires 6-year terms for auditors and Italy which mandates annual rotation of auditors (a possibility SOX requires US regulators to study).

${ }^{40}$ SOX imposes the requirement on non-US issuers only for annual reports (Form 20-F), not interim reports (Form 6-K) which do not contain financials.

41 See Lawrence A. Cunningham, Semiotics, Hermeneutics and Cash: An Essay on the True and Fair View, 29 N.C. J. INTL L. \& COMM. REG. 893 (2003).

42 The SEC struggled with various manifestations of the American character of SOX concerning various control devices. A good example concerns the concept of financial experts. SOX required the SEC to adopt rules requiring quarterly and annual disclosure of whether at least one audit committee member is a "financial expert" and, if not, why not. The SEC is directed to define the term financial expert, considering a person's education and experience and probable knowledge of GAAP, financial statements, audit committee functions, internal accounting controls and preparing or auditing financial statements. SEC rules defined the concept to require an understanding of GAAP and financial statements, experience preparing, auditing, analyzing or evaluating financial statements of the type the registrant reports or supervising such a registrant, and an understanding of internal controls and audit committees. Means of obtaining requisite expertise include education and direct or indirect experience. For non-US issuers whose financial statements are prepared in accordance with their home-country accounting principles rather than US GAAP, these provisions refer to that set of accounting principles.

${ }^{43}$ SOX required the SEC to adopt rules requiring stock exchanges to prohibit listing securities of companies not complying with the following audit committee rules. First, the committee must be directly responsible for appointing, paying, and supervising outside auditors. Second, all committee members must be independent and not collecting fees from the registrant (by consulting or otherwise). Third, committees must establish procedures to promote employee reporting of misconduct and protect reporting employees (whistle-blowers). Fourth, committees must be empowered to retain independent counsel and other advisors. Fifth, the company must provide sufficient funding, as the committee determines, to pay outside auditors and committee advisors. For non-US issuers, SEC rules permit compliance with home-country requirements on these matters, including permitting non-management employees to serve on audit committees, allowing shareholder selection or ratification of auditors rather than the audit committees, permitting alternative bodies such as a board of auditors to fulfill auditor oversight roles, and modulating rules relating to audit committee members belonging to company affiliates or governmental entities.

${ }^{44}$ See Cunningham, An Essay on the True and Fair View, supra. 
${ }^{45} \mathrm{Cf}$. CHARKHAM, supra, at 6 (introducing German comparative corporate governance by noting that "Looking at the formal framework tells only a fraction of the story: the attitudes people have and their patterns of behaviour are just as important" and that "transplanting formal structures will not necessarily produce identical patterns of behaviour").

${ }^{46}$ See, e.g., Jouy-en-Josas, French Employers' Representative Concerned by New US Corporate, Agence France Pressee (Aug. 28, 2002) (quoting a vice president of the French employers' federation Medef: "Imposing respect for the laws of your own country on people not under its jurisdiction is a precedent with extremely far-reaching consequences. . . Laws passed in one country can not be applied to citizens of other countries.").

47 Since 1856, France has sought to promote the use and independence of boards and auditors. Richard M. BuXbaum \& Klaus J. Hopt, LEGAl HARMONIZATION AND THE BusinesS ENTERPRISE: CORPORATE AND CAPITAL MARKET LAW HARMONIZATION POLICY IN EUROPE AND THE U.S.A. (1988), 176-189. It has only lately joined the vanguard for including lots of employees in the interior of corporate governance. See infra note 52.

48 See Economy: The Financial Crisis: A Problem of Confidence? (Economie: La Crise Financiére, Un Probléme de Confiance?), L'Humanie (Oct. 11, 2002) (available at www.humanite.presse.fre) (new Finance Minister Francis Mer's push for parliamentary discussion of new laws based on "la loi américaine Sarbanes-Oxley" in early 2003).

49 See Daniel Bouton (Committee Chairman), Promoting Better Corporate GOVERNANCE IN LISTED COMPANIES (Sept. 23, 2002) (available at http://medef.net). The Bouton Commitee published a 25-page report, commissioned by leading business groups the MEDEF and AFEP-AGREF Emphasized are greater board independence, including on audit committees, and tighter restrictions on stock options. If the report contrasts with SOX, it does so mainly by greater emphasis on structural integrity that justifies confidence rather than on detailing enforcement mechanisms.

50 See Laure Belot, The United States and Europe Answer the Financial Crisis in Dispersed Order, LE Monde (Sept. 20, 2002) (avaialble at www.lemonde.fr) (quoting JeanRené Buisson, general manager of Danone: "Les entreprises américaines étaient peu préparées à ce type de loi. En France, nous avons un système de régulation qui fonctionne. La loi Sarbanes ne nous pose pas de problème particulier." [translation: "American corporations were poorly prepared for this type of law. In France, we have a regulatory system which functions well. Sarbanes-Oxley does not pose any problems for us in particular.']; and Robert Castaigne, CFO of TotalFinaElf: "Dans son esprit, cette loi ne nous dérange pas, mais on ne voudrait pas que cela entraîne trop de lourdeurs administratives." [translation: "In spirit, Sarbanes-Oxley is not bothersome to us, provided that complying with it does not present too many administrative headaches."].)

51 In France, the Presidents-Directeurs-Generaux exhibit an "overused ability to browbeat company boards." See Paul Raynes, breakingviews.com (Sept. 24, 2002). Hence 
similar sorts of reforms to SOX are pursued in France: more board independence, including on audit committees. SOX's provisions map on reasonably easily.

${ }^{52}$ Id. Indeed, reformers tended to characterize changes in French corporate law in 2002 called the New Economic Regulations as a "move the French public company more towards the German model." But this characterization seems strained, for the proposals appear to have as much in common with the US/UK model. They follow the German model in giving workers greater rights and representation through works councils and rights to vote on certain fundamental corporate change such as large asset sales, but also follow the US/UK model in giving the board an explicit strategic role in corporate management and splitting the identity of the CEO and board chairman. LARRY CATA BACKER, COMPARATIVE CORPORATE LAW (2002), at 209.

${ }^{53}$ Prime Minster Blair contacted President Bush, see Gavin Hinks, Bonus Threat to UK FDs, Mgmt. Consultancy (Dec. 28, 2002); UK Trade Secretary Patricia Hewitt reportedly lobbied US Commerce Secretary Don Evans, see Michelle Perry, Hewitt Tells US to Lay Off UK Firms, FIN. DIR. (Oct. 10, 2002); subsequently, Secretary Hewitt recanted on the protest, denying she had ever made it, see Larry Schlesinger, Hewitt Denies Lobby Against Sarbanes-Oxley, FIN. DIR. (Jan. 17, 2003); and UK economic secretary Melanie Johnson met with SEC Chairman Harvey Pitt, see David Teather \& Julia French, Grubman Aids US Clean-Up, GUARDIAN (Oct. 11, 2002).

${ }^{54}$ E.g., Philip Smith, BP Ready to Accept Sarbanes Oxley, MgMt. Consultancy (Dec. 28, 2002) (British Petroleum's CEO's office released a statement: “Our CEO [Lord Browne] would have no difficulty signing his name to a statement saying that the results we publish and the data we present to our investors is a fair record of what the company is doing.").

55 A related debate arising simultaneously in the UK and US concerned audit firm rotation, which SOX requires, and audit partner rotation, which SOX directs the SEC to study. See Cunningham, The Sarbanes-Oxley Yawn, supra.

${ }^{56}$ Nippon Telegraph, Canon and NEC issued press releases criticizing provisions of SOX that "unnecessarily" affect foreign businesses. See LEGAL MEdia Group, Sarbanes-Oxley Risks Alienating Foreign Investors (Sept. 29, 2002) (noting also that these companies "have the lobbying support of the Japanese Business Federation to campaign for exemptions"). Canon CEO Fujio Mitarai made the case that Japanese corporate laws already protect investors equally as well as SOX would, emphasizing, "I don't think that our management structures and in-house controls have to match U.S. standards." See News Analysis, Will Foreign Boards Play by U.S. Rules?, BUS. WK. ONLINE (Dec. 6, 2002).

57 Daiwa Securities Group Inc. chose to delay its listing indefinitely specifically because of the expanded procedural requirements and potential increased liability risk SOX poses for corporations and their executive officers. See id.. 
${ }^{58}$ See WALl ST. J. (Aug. 2002) (quoting Toshiyasu Iiyama, a spokesman for Nomura Holdings Inc., Japan's biggest brokerage firm whose shares recently began to trade on the NYSE, as simply saying, "We intend to comply with this new law. A rule is a rule."). Japanese electronics giant Sony has also stated publicly that it has every intention of complying with SOX.

${ }^{59}$ One example is the definition of executives subject to SOX's rules forbidding officers and directors to trade securities received by them as employees when the company's pension plan participants are restricted. Violations of this blackout rule call for forfeiture of the profits made to the company without regard to intent. SEC rules narrow the scope of the concept to a foreign private issuer's principal executive, financial and accounting officers of the registrant. See Securities and Exchange Commission, Insider Trades During Pension Fund Blackout PERIODS, 17 CFR Parts 240, 245 and 249 [Release No. 34-46778; IC-25795; File No. S7-44-02] (Nov. 6, 2002).

${ }^{60}$ A leading and vocal critic was outspoken European Commissioner Frits Bolkestein, who criticized SOX as overreaching extra-territorialism, and who identified the seven areas of specific objection, including those relating to PCAOB regulation of global auditors.

61 Aude Genet, EU Seeks Corporate Action Plan to Avoid US-Style Scandals, AGENCE FRANCE PRESSE (Oct. 1, 2002) ("Brussels wants EU firms listed in the United States and conforming to international guidelines to be exempted from strict new US rules.").

${ }^{62}$ In fact, the EC designated a task force to address corporate governance and accounting in 2001, with its mission broadened in April 2002 in Enron's wake. The focus, as under SOX, is on audit committees and independent directors (called non-executive directors in Europe).

63 E.g., Frits Bolkestein, Speech: Speeding Up the Consolidation of European FINANCIAL MARKETS (July 11, 2002).

${ }^{64}$ The EC Commission SE Statute of 2001 refrains from encroaching national territory, opting instead for incremental harmonization. It expressly announces that "a single European model is not intended," explaining that "an SE does not need uniform Community rules." Statute, Art. 9.

65 See Backer, supra, at 610 ("It appears that, since the Statute places such a heavy emphasis on the company law of the Member States for the governance of SEs, integration of company law through the SE may depend for its long term success on the ability of the EU to effectively harmonize Member State Company Law.").

${ }^{66}$ Cf. John C. Coffee, Jr., The Future as History: The Prospects for Global Convergence in Corporate Governance and Its Implications, 93 Nw. U. L. REV. 641 (1999).

${ }^{67}$ See BuXBAUM \& HoPT, supra, at 15-20. 
68 See Mark J. Roe, Delaware's Competition, 117 HARV. L. REV. (forthcoming 2003); Renee Jones, Rethinking the Federalism Debate in Corporate Law, 29 J. CORP. L. (forthcoming 2004).

${ }^{69}$ See Richard English, Company Law in the European Single Market, 1990 B.Y.U. L. REV. 1413, 1435-36 ("The prevalence of the siege social rule, a distinctive feature of the laws in most Member States, has tended to remove the possibility that the laws of corporate governance would progressively evolve into a state of greater convergence.")

70 See, e.g., Suvarn Valaisathien, Strict Enforcement of Rules is Vital, THE NATION (Thailand) (Sept. 16, 2002); Azeta Mercantil Online, Brazilian Companies Endorse SOX (Sept. 2, 2002); Mikhail Overchenko et al., CEOs Not Worried About SEC 'Vow,' Moscow TIMES (Aug. 30,2002) (Russia).

71 See EU Statute for a European Company, Council Regulation (EC) No. 2157/2001 of 8 October 2001 on the Statute for a European company (SE), OJ L 294, 10/11/2001 P. 0001-0021. This theme is also evident in the European court's reversal of a series of decisions made by its Competition Committee that would have blocked various merger transactions. See The EC's Trustbuster on Trial, BuS. WK. OnLINE (Nov. 11 2002) (noting three reversals in five months); see also http://www.lexecon.co.uk/news/recent.php (click on link for ruling of the European Court of First Instance on the proposed Tetra/Sidel merger).

72 Global audit rule discussions were routinely described as responding to "US business scandals." E.g., Andrew Parker \& Victor Mallet, Big Four Hit at French Audit Proposal, Fin. T. (Nov. 22, 2002).

73 E.g., Credit Lyonnais v. Pathe Comm. Corp., 1991 WL 277613, 17 Del. J. Corp. L. 1099 (1991).

${ }^{74}$ See Jeffrey N. Gordon, An American Perspective onthe New German Anti-takeover Law, DIE AKTIENGESELLSCHAFT, vol. 12 (Dec. 2002), also available at www.ssrn.com.

75 Nor are the contemporary scandals historical aberrations, for scandal and failure characterizes the histories of all societies. E.g., Ballwieser, supra, at 1225 ("Great distress consequent upon the failure of the country's second largest insurance group and one of the Big Four banks led to the introduction of emergency decrees under the stock corporation law by the head of state in 1931"). These included new rules detailing the form and content of annual accounts and directors' reports and requiring audited accounts (the latter marking the birth of the German auditing profession).

${ }^{76}$ See AGENCE FRANCE PRESS, Germany Steps Up Fight against Accounting Fraud (Sept. 3,2002 ) (mentioning report of rolling out a 10-point program).

${ }^{77} I d$. This response is identical to a key response made in SOX. 
78 See John Hooper, www.gUARDIAN.COM (May 28, 2001).

79 A different sort of corporate "scandal" casts an entirely different spin, where a major German corporation rebuked both German and US accounting principles in favor of its own view that conflicted with both. The company is Porsche, an outspoken critic of both SOX and German rules. One German rule requires, as do US rules for domestic registrants, quarterly financial statements. Porsche shuns the practice, preferring to publish only half-year and year-end financials. Sticking with this position got it expelled from a leading German stock market index by the Deutsche Bourse, operators of the Frankfurt Stock Exchange. 27, 2002).

${ }^{80}$ Mark Landler, German Technology Stock Market to Be Dissolved, N.Y. TIMES (Sept.

${ }^{81}$ Founded by Bodo Schnabel in 1995, the company used German accounting principles to show 2001 sales of $\$ 90$ million-driving a market cap of more than $\$ 1$ billion-when actual sales were \$2 million and the rest were the product of phony purchase orders made by a fictitious Hong Kong company Schnabel created. KPMG certified ComRoad's accounts, German analysts such as Deutsche Bank AG trumpeted its stock, and HVB Group (Germany's second largest bank) supported ComRoad's secondary equity offering. In February 2002, a forensic audit conducted by Rodl \& Partner GmBH revealed the scam; in November 2002, Schnabel was sentenced to seven years in prison. See generally Matthew Lynn, The Story of a Company That Was Not There, TAIPEI TIMES (May 4, 2002) (available at www.taipeitimes.com).

${ }^{82}$ See WAll St. J. (Jan. 28, 2003).

${ }^{83}$ George Parker \& Francesco Guerra, Accounting Controls on EU Budget 'Unreliable' FIN. T. (Aug. 1, 2002).

84 Id.

85 See also George Parker \& Francesco Guerra, Brussels Turns on Softly Spoken Accountant, FIN. T. (Aug. 1, 2002 (profile of Marta Andreasen, the chief accountant, and her tenure from January to May 2002, viewing treatment as vilifying). One objection the chief accountant made concerned "officials' ability to change financial details without leaving any electronic fingerprints"- a criticism equally apt of the US scandals precipitating SOX.

${ }^{86}$ Parker \& Guerra, Accounting Controls on EU Budget 'Unreliable', supra. See also George Parker \& Francesco Guerra, Accounts Control Problems Under Merciless Spotlight, FIN. T. (Aug. 1, 2002).

${ }^{87}$ Parker \& Guerra, Accounting Controls on EU Budget 'Unreliable', supra.

88 See generally Lawrence A. Cunningham, The Appeal and Limits of Internal Controls to Fight Fraud, Terrorism, Other Ills, 29 J. CORP. L. (forthcoming 2004). 
89 Christopher Lee Heftelo, Corporate Governance in Japan: The Position of Shareholders in Publicly Held Corporations, 5 HAW. L. REV. 135 (1983).

${ }^{90}$ Id. ("loyalties not generally to the shareholders but to the corporate insiders and the employees."). Most directors tend to be insiders or if outsiders hardly independent (products of seniority system, become director after retirement, retirees from company's main bank, sister companies or governmental agencies). Id.

91 Masatoshi Kuroda, Japan Group Accounts (in 2 DIETER ORDELHEIDE \& KPMG, TRANSNATIONAL ACCOUNTING (2d ed. 2001), at 1817 \& 1827 (noting the bankruptcy of Sanyo Special Steel in March 1965).

92 See Bryan Rahman, Tainted Snow Brand Pays Price of Scandal, FIN. T. (Nov. 22, 2002).

93 See Mark Maremont, Jesse Eisinger \& John Carreyrou, How High-Tech Dream Shattered in Scandal at Lernout \& Hauspie, WALL ST. J. (Dec. 7, 2000) (chronicling fate of Lernout \& Haspie Speech Products NV, a leading maker of speech recognition software whose \$10 billion market cap turned to bankruptcy following a massive accounting scandal quite similar to those prevalent in the US tech sector of the late 1990s, including phony barter transactions and premature revenue recognition).

94 See Alison Langley, Amid Turmoil at Swiss Life, Its Chairman Plans to Leave, N.Y. TIMES (Nov. 8, 2002) ("The traditionally clubby Swiss business world has been rocked by financial debacles, revelations about unreported executive compensation, plunging share prices, shareholders' outrage and executives' departures."). Long Term Strategy, a Swiss fund whose accounting problems brought its downfall earlier in 2002, may have had links to Swiss Life. Id.

95 See China Court Clears Path to Suits Against Firms, Wall St. J. (Jan. 10, 2003) (noting China Supreme People's Court ruling permitting private shareholder lawsuits as part of an effort to promote investor confidence which had "soured in recent years amid a series of scandals in which executives lied about earnings to boost stock prices."). Other Chinese governmental responses included overhauling the accounting profession, enhancing financial disclosure, and increasing penalties. Id. This experience and reform effort echoes the US experience and SOX of the same period.

${ }^{96}$ See Securities And ExChange Commission, 2001 AnNuAl REPORT, at 24.

97 Exemplars of variations on these restated themes include MARK ROE, STRONG MANAGERS, WeAK Owners (1997); Mark J. Roe, Chaos and Evolution in Law and Economics, 109 HARV. L. REV. 641 (1996); Henry Hannsman \& Reneir Kraakman, The End of History for Corporate Law, 89 GEO. L.J. 439 (2001). 
${ }^{98}$ E.g., Michael Bradley, Cindy A. Schipani, Anant K. Sundaram \& James P Walsh, The Purposes and Accountability of the Corporation in Contemporary Society: Corporate Governance at the Crossroads, 62 L. \& CONTEMP. PROBS. 9, 67-77 (1999).

99 Id. (noting 8 German companies newly listing ADRs in the US since 1996: n.390: Celanese; Deutsche Telekom, Fresenius Medical Care, Pfeifer Vacuum, SAP, SGL Carbon, VEBA—see nyse.com/international.htm)

${ }^{100}$ Id. Anecdotally, consider a striking sight on numerous Paris street corners: day trading firms. While not nearly as ubiquitous as the Paris café, the sight is telling.

${ }^{101} I d$.

${ }^{102}$ E.g., RoE, Strong MANAGERs, WeAK OWNERS, supra.

${ }^{103}$ Pierre Legrand makes the point that despite advertised convergence, EU convergence is more apparent than real, more at the level of harmonic legal rules, with persistent epistemological differences in mentality, and concludes that at that level differences are irreducible. This may explain more than is observed, but there is a deep kernel of truth in the initial parts of the argument.

104 See generally, Cunningham, An Essay on the True and Fair View, supra.

105 See Teemu Ruskola, Conceptualizing Corporations and Kinship: Comparative Law and Development Theory in a Chinese Perspective, 52 STAN. L. REV. 1599, 1713-1728 (2000) (criticizing convergence theorists on grounds that they assume the "telos of legal development is a foregone conclusion," and arguing instead that "modernity" and "tradition" are not "mutually exclusive historical trajectories" and that therefore "several opposing tendencies may be simultaneously entrenching").

${ }^{106} I d$.

107 See Cynthia A. Williams, The Securities and Exchange Commission and Corporate Social Transparency, 112 HARV. L. REV. 1197 (1999); compare William W. Bratton, Confronting the Ethical case Against the Ethical Case for Constituency Rights, 50 WASH. \& LEE L. REV. 1449 (1993) with Stephen M. Bainbridge, Corporate Decisionmaking and the Moral Rights of Employees: Participatory Management and Natural Law, 43 VILL. L. REV. 741 (1998).

108 See John Merryman, On the Convergence (and Divergence) of the Civil Law and the Common Law, in New Perspectives fOr A COMMON LAW OF Europe 196, 233 (Mauro Cappelletti ed., 1978) ("a focus on rules is superficial and misleading: superficial because rules literally lie on the surface of legal systems whose true dimensions are found elsewhere; misleading because we are led to assume that if rules are made to resemble each other something significant by way of rapprochement has been accomplished.").

109 See supra Part I. 
${ }^{110}$ See Coffee, The Future as History, supra. The tendency is even stronger with respect to state copying of leading securities laws. See Mark Gillen \& Pittman Potter, The Convergence of Securities Laws and Implications for Developing Securities Markets, 24 N.C.J. INT'L L. \& COM. REG. 83 (1998) (noting that Malaysia and Singapore corporate laws were borrowed from Australia and the UK and that their takeover-related securities laws were copied from the UK and their anti-fraud provisions form the US).

${ }^{111}$ KISSINGER, supra, at 217; see also MANDELBAUM, supra, at 293-304 (chronicling the rise of market power, opposition to it, and the problems of its successes).

${ }^{112}$ It appears that no or little such expressions of comity were ventured before SOX's passage, furnished a grounds for criticism abroad, and was not ameliorated until mid-October (nearly 3 months after passage) when then-SEC Chairman Harvey Pitt gave a speech to British accountants in Brussels, followed a week later by an interactive videoconference hosted by senior SEC officials and intended for non-US issuers and auditors and their advisors. Key topics focused on the machinery going into effect in SOX's wake. SEC representatives met with counterparts abroad in December 2002 and rolled out proposed exemptions in late January 2003, 7 months after SOX was enacted.

113 See Stephen M. Walt, Keep the World Off Balance: Self Restraint and U.S. Foreign Policy, KSG WORKING PAPER 00-013 (Oct. 2002) (available from www.ssrn.com) (endorsing US foreign policy that wields its power with restraint, as a "benevolent hegemon," exercising less power than it is capable of exercising to signal its credibility, particularly on lower level foreign policy matters).

${ }^{114}$ Congressional committees are the chief forum for conducting such exercises, which are routinely done for a wide variety of legislation concerning international relations or foreign policy. These include matters of international tax, treaties, global or regional narcotics controls, and global anti-money laundering strategies. The Senate Committee on Foreign Relations and the House Committee on International Relations have jurisdiction over legislation impacting US relations with other nations, including those affecting commercial interests of US entities abroad. Senator Sarbanes is a member of this Committee but no record evidence indicates that it was involved in SOX (Oxley is not a member of this House Committee). SOX was vetted by the House Committee on Financial Services and there is no record evidence that this Committee examined its international relations dimensions.

${ }^{115}$ KIESO, INTERMEDIATE ACCOUNTING, supra, at 7.

${ }^{116}$ In 1997, the SEC noted a 4700\% increase from 1980 to 1995 in the volume of trading by US investors in securities of non-US issuers.

117 This is a simple reversal of the existing framework that gives the SEC general authority under Section 36 of the Securities Exchange Act of 1934 to exempt issuers and transactions (including private foreign issuers individually or as a class) from any Exchange Act 
provision or SEC rule or regulation if it determines doing so is in the public interest and consistent with investor protection. Exemption authority does not extend to criminal laws.

118 The determination should also ascertain that exemptions would not alter the competitive advantages of US versus non-US companies in raising capital in the US markets or confuse US investors. See Richard C. Breeden, Foreign Companies and U.S. Securities Markets in a Time of Economic Transformation, 17 FORD. INT'L L. J. 77, 90 (1994) (expressing concern that foreign exemptions put domestic issuers at a competitive disadvantage compared to non-US issuers and also risks producing investor confusion).

119 The number one candidate for designation as a favored nation is Canada, already given functionally given such status under the SEC's multijurisdictional disclosure project that permits Canadian companies to file home country documents given substantial comparability of US and Canadian accounting, disclosure and regulatory systems. See MultiJURISDICTIONAL Disclosure AND MODIFICATIONS TO THE CURRENT REGISTRATION AND REPORTING SYSTEM FOR Canadian Issuers, Securities Act Release No. 33-6902, 56 Fed. Reg. 30,036 (June 21, 1991). Other immediate candidates for designation as favored nations would include most of the countries of Europe (certainly the UK, Germany, and France) and Japan, as well as Australia, the Netherlands, Israel and perhaps others recognized as complying with the Core Principles articulated in IOSCO's 1998 Objectives and Principles of Securities Regulation. Countries for immediate exclusion from such a designation are those the SEC, as part of the US Financial Action Task Force, has designatged as non-cooperative jurisdictions (NCJs), those out of compliance with relevant international standards with respect to financial regulatory systems and international cooperation on matters such as anti-money laundering efforts.

${ }^{120}$ KISSINGER, supra, at 82 ("too much American domestic legislation is being applied to close allies in their own countries").

121 The favored nation concept is akin to mutual recognition proposals developed on behalf of the EU calling for the US and the EU to recognize each other's complying members. A broader current proposal calls for mutual recognition of stock exchanges across the Atlantic, enabling domestic investors to invest directly in foreign issuers through a foreign exchange operating domestically with no need for issuers to comply with foreign rules or list on foreign exchanges. See Benn Steil, Building a Transatlantic Securities Market (Feb. 2003) (available from www.isma.org). 